\title{
Single-nucleotide Polymorphisms in the p53 Signaling Pathway
}

\author{
Lukasz F. Grochola, Jorge Zeron-Medina, Sophie Mériaux, and Gareth L. Bond \\ Ludwig Institute for Cancer Research, University of Oxford, Oxford, OX3 7DQ, United Kingdom \\ Correspondence: gareth.bond@ndm.ox.ac.uk
}

The p53 tumor suppressor pathway is central both in reducing cancer frequency in vertebrates and in mediating the response of commonly used cancer therapies. This article aims to summarize and discuss a large body of evidence suggesting that the p53 pathway harbors functional inherited single-nucleotide polymorphisms (SNPs) that affect p53 signaling in cells, resulting in differences in cancer risk and clinical outcome in humans. The insights gained through these studies into how the functional p53 pathway SNPs could help in the tailoring of cancer therapies to the individual are discussed. Moreover, recent work is discussed that suggests that many more functional p53 pathway SNPs are yet to be fully characterized and that a thorough analysis of the functional human genetics of this important tumor suppressor pathway is required.

$\mathrm{O}$ cellular stress, the $\mathrm{p} 53$ protein is stabilized and regulates the expression, cellular location, and activity of key effectors of cellular processes, such as DNA repair, cell-cycle arrest, senescence, and apoptosis (Levine 1997; Riley et al. 2008). These p53-mediated responses are crucial both in reducing cancer frequency in vertebrates and in mediating the response of commonly used cancer therapies (Johnstone et al. 2002; Lozano and Zambetti 2005; Haupt and Haupt 2006). The study of the somatic genetics of the p53 pathway in cancer cells and tumors has proven useful in the development of targeted therapies and has shown that the p53 mutational status can serve as an independent prognostic indicator in some types of cancers (Soussi and Wiman 2007; Vazquez et al. 2008). This article aims to summarize and discuss a large body of evidence that suggests that the inherited genetics of the p53 pathway also could be used to further define patient populations in their abilities to respond to stress, suppress tumor formation, and induce p53 activity on treatment with DNA damaging therapies (Bond and Levine 2007; Vazquez et al. 2008). First, several studies are reviewed that provide evidence that two important genes in this signaling pathway, the p53 and Mdm2 genes, harbor high frequency, functional single-nucleotide polymorphisms (SNPs) that affect p53 signaling, and alter cancer risk and clinical outcome. The insights gained through

Editors: Arnold J. Levine and David P. Lane

Additional Perspectives on The p53 Family available at www.cshperspectives.org

Copyright (C) 2010 Cold Spring Harbor Laboratory Press; all rights reserved; doi: 10.1101/cshperspect.a001032

Cite this article as Cold Spring Harb Perspect Biol 2010;2:a001032 
L.F. Grochola et al.

these studies into how the functional p53 pathway SNPs interact with known cancer risk factors and therapeutics are highlighted and their potential translational relevance is discussed. Lastly, other less studied, potential functional p53 pathway SNPs are reviewed, as well as recently published strategies designed to identify and characterize novel functional SNPs.

\section{FUNCTIONAL p53 PATHWAY SNPs}

\section{p53 Codon 72}

The SNPs in the p53 pathway that are most frequently studied are found in the p53 and MDM2 genes ( $p 53$ codon 72 [Harris et al. 1986], rs1042522, C/G; MDM2 SNP309 [Bond et al. 2004], rs2279744, T/G). The different alleles of p53 codon72 encode either a proline (p53-codon72-Pro) or arginine ( $\mathrm{p} 53$-codon72Arg) residue and were first reported in 1988 by Buchman and colleagues (Buchman et al. 1988). The amino acid encoded by codon 72 resides in a polyproline region of $\mathrm{p} 53$ that is located between the transactivation and the DNA binding domains. This proline-rich region has been shown to be important for p53 function, especially for its ability to induce apoptosis (Walker and Levine 1996; Sakamuro et al. 1997).

The first study to provide evidence that the two different p53 isoforms encoded by the p53 codon72 SNP are not functionally equivalent was published in 1999 (Thomas et al. 1999). For example, the authors observed that p53codon72-Arg was more efficient at both suppressing transformation by the oncogenes E7 and EJ-ras and initiating apoptosis. In a later report, Dumont and colleagues noted that p53codon72-Arg has a stronger capacity to induce apoptosis (Dumont et al. 2003). Specifically, by using a temperature-sensitive p53 mutant, they observed that p53-codon72-Arg is more efficiently translocated to the mitochondria, where it interacts with proapoptotic proteins such as GRP75 and Hsp60, thereby triggering apoptosis. Subsequently, three additional studies, using various p53-inducible isogenic cell lines, also noted the greater apoptotic potential of p53-codon72-Arg both in the presence (Sullivan et al. 2004) and absence (Pim and Banks 2004; Bergamaschi et al. 2006) of chemotherapeutics. Interestingly, one study presented data supporting a transcriptional-dependent mechanism to explain the different apoptotic potentials of the p53 isoforms. Specifically, Sullivan et al. studied H1299 lung carcinoma cell lines containing either inducible p53-codon72Pro or p53-codon72-Arg and immortalized B-cell lines with the differing genotypes at this locus (Sullivan et al. 2004). In this report, the induction of p53-codon72-Arg and treatment with chemotherapeutics were shown to significantly induce up to eightfold more apoptosis than p53-codon72-Pro and the chemotherapeutics. The authors showed that this increased apoptosis associated with an elevated transcription of PUMA, PERP, and AIP1, three known apoptotic effectors and targets of p53 transcriptional regulation, but not of two other p53 targets that are not direct effectors of apoptosis (MDM2 and p21). Similar findings were observed in immortalized B-cell lines derived from individuals with wild-type p53 and differing genotypes at the codon72 locus (Sullivan et al. 2004). A subsequent report showed that this difference in transcriptional regulation of downstream effectors was mediated, at least in part, by a higher binding affinity of p53-codon72-Pro to the protein iASPP (Bergamaschi et al. 2006). Together with similar observations from other cell-based studies (Bonafe et al. 2002; Dumont et al. 2003; Pim and Banks 2004; Sullivan et al. 2004), these data support a model that in the context of wildtype p53, p53-codon72-Arg can be better at mediating the p53-dependent apoptotic response.

Intriguingly, multiple studies have shown that the p53 codon72 SNP can affect apoptosis not only in the context of the wild-type p53 sequence but also in the context of p53 that has sustained somatic mutations. Interestingly, three reports suggest the mtp53-codon72-Pro isoform can associate with higher levels of apoptosis. In two studies, either Saos-2 cells (human osteogenic sarcoma) (Bergamaschi 
et al. 2003) or H1299 cells (human lung cancer) (Vikhanskaya et al. 2005) were stably transfected with a series of p53 mutants either proline (mtp53-codon72-Pro) or arginine (mtp53-codon72-Arg) for codon72. Together, both studies clearly show that in the context of some p53 mutations and the addition of certain chemotherapeutics, cells that express mtp53-codon72-Pro undergo more apoptosis than cells that express mtp53-codon72-Arg.

Two studies have proposed that several common mutants of mtp53-codon72-Arg bind with a greater affinity to a 533 family member, the tumor suppressor protein $\mathrm{p} 73$, thereby inhibiting its ability to induce apoptosis (Marin et al. 2000; Bergamaschi et al. 2003). For example, in an isogenic cell-based model, Marin and colleagues (Marin et al. 2000) showed that conformational p53 mutants are capable of binding to and inactivating $\mathrm{p} 73$. This protein-protein interaction abrogates p73 ability to induce apoptosis by interfering with its DNA binding potential. Importantly, they observed that mtp53-codon72-Arg bound p73 with greater affinity than mtp53-codon72-Pro.

The precise molecular mechanism underlying these noted differences in apoptosis seems to merit further study (Vikhanskaya et al. 2005), but the persistent observations that different alleles at codon 72 collaborate with the p53 mutational status to influence a cell's ability to undergo apoptosis suggest the potential translational relevance of these studies. Specifically, knowing an individual's genotype at the p53 codon72 locus and the p53 mutational status of their tumor could help subclassify the patient according to his/her probability to respond to certain chemotherapeutic agents to determine the best therapeutic strategy (Fig. 1). Studies of 70 patients with inoperable, advanced head and neck squamous cell carcinomas, who all received cisplatin-based chemo-radiotherapy, support this hypothesis (Bergamaschi et al. 2003; Sullivan et al. 2004). Specifically, those individuals who retained wild-type p53 in their tumors were found to associate with better response rates and overall and progression-free survival (Sullivan et al. 2004). However, in those patients that retained a wild-type p53, individuals with wtp53-codon72-Arg associated with the best response rates, and overall and progression-free survival, in concordance with its higher apoptotic potential. In those patients with mutant p53, individuals with mtp53codon72-Pro associated with the best overall and progression-free survival, also in line with its relatively high apoptotic potential compared with cells with mtp53-codon72-Arg (Bergamaschi et al. 2003). Interestingly, those patients harboring the conformational p53 mutations that bind with greater affinity to p73 showed the greatest allelic differences.

\section{MDM2 SNP309}

p53 cellular activity is tightly regulated by many cellular protein-protein interactions and various forms of posttranslation modifications, (Murray-Zmijewski et al. 2008). One of the most intensely studied regulations is that by the $\mathrm{Mdm} 2$ oncogene product (Momand et al. 1992). MDM2 has been shown to bind directly to p53 and thereby inhibit its ability to activate transcription, regulate its cellular localization, and target it for proteosomal degradation. Interestingly, MDM2 forms a negative-feedback loop with $\mathrm{p} 53$, as $\mathrm{Mdm} 2$ transcription can be directly positively regulated by p53 (Momand et al. 1992; Haupt et al. 1997). The importance of this interaction in regulating p53-dependent tumor suppression is highlighted by the observations made in multiple mouse models that even a modest change of MDM2 expression levels can affect p53-dependent tumor suppression in mice (Lane 2005; Poyurovsky and Prives 2006). For example, it has been shown that just a 20\% reduction of MDM2 levels in mice leads to a significant reduction in intestinal adenoma formation (Mendrysa et al. 2006). It has been reasoned that such observations allow for the possibility that changing just a few (or even just one) base pair(s) in regulatory regions of the gene could alter the levels of MDM2 activity enough to affect the p53 pathway and 
L.F. Grochola et al.

A

B

DNA-damage-inducing therapies
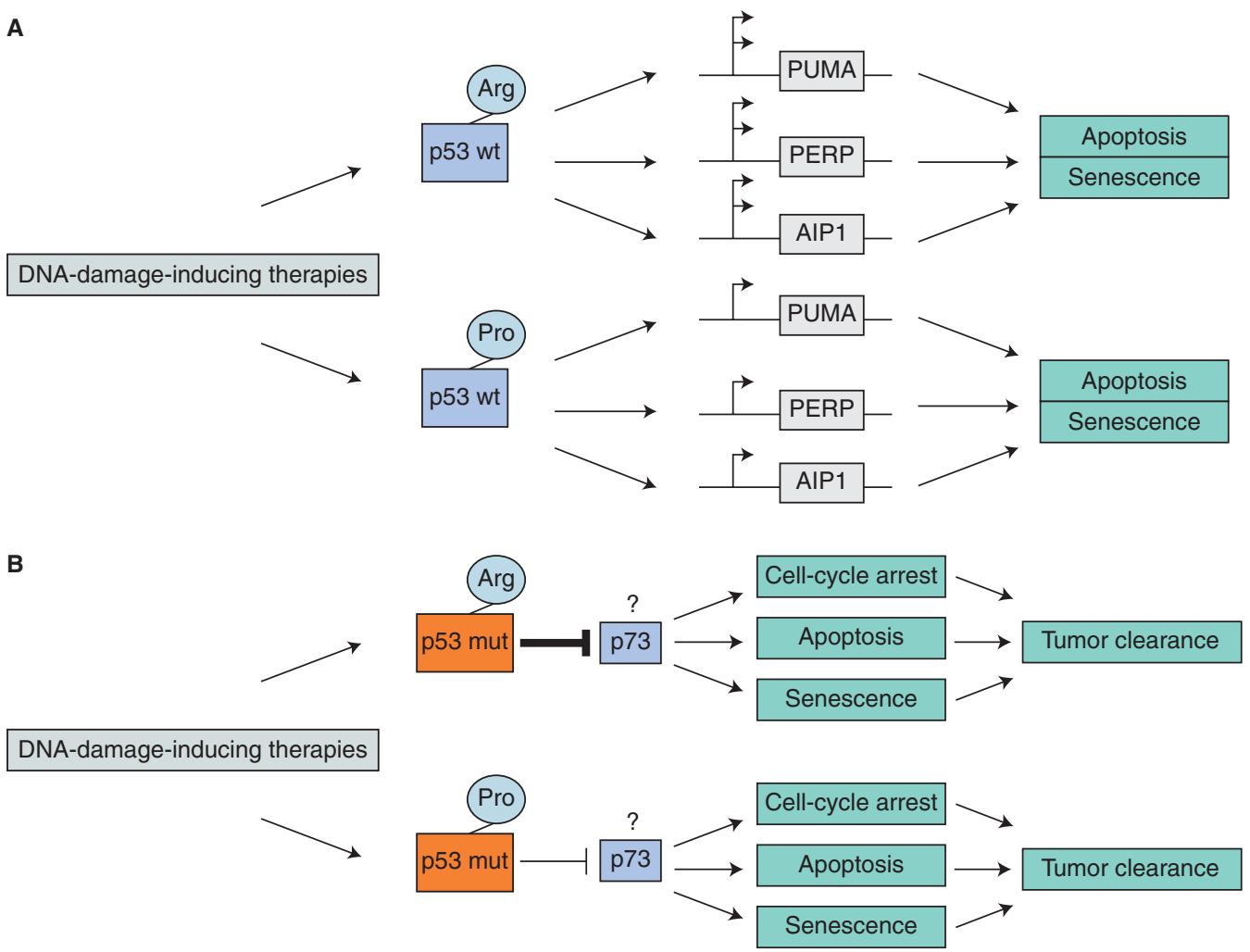

Figure 1. Incorporating information of both the inherited and somatic genetics of the p53 gene could further define patient populations in their abilities to respond to certain therapies. (A) Some studies suggest that cells from individuals with the proline (Pro) allele of p53 codon72 will undergo less apoptosis in response to DNA-damage-inducing therapies compared with individuals with the arginine (Arg) allele of p53 codon72. This has been suggested to be caused by less transcriptional activation of apoptotic effectors. (B) Other studies suggest that cancer cells with somatic p53 mutations from individuals with the proline (Pro) allele of p53 codon72 will undergo more apoptosis in response to DNA-damage-inducing therapies compared with individuals with the arginine (Arg) allele of p53 codon72. This has been suggested to be potentially because of an enhanced inhibition of the p73 tumor suppressor by mtp53-codon72-Arg.

therefore cancer in humans (Bond et al. 2004). Extensive study of a heritable, human genetic variant in the form of a SNP in the promoter of MDM2 (MDM2 SNP309 T/G) has lent support to this hypothesis (Bond et al. 2004; Bond and Levine 2007; Hu et al. 2007c).

MDM2 SNP309 is found at position 309 in the first intron of the MDM2 oncogene, which serves as a transcriptional enhancer region (Bond et al. 2004). Through computational analysis, the $\mathrm{T}$ to $\mathrm{G}$ allelic change introduced by SNP309 was predicted to increase the affinity of the Sp1 transcription factor by extending the length of a Sp1 binding site, which was subsequently validated through in vitro DNA-protein binding assays and reporter plasmid, cell-based assays (Bond et al. 2004). This model suggested that the G-allele of SNP309 would lead to increased transcription of MDM2, resulting in the attenuation of the p53 stress response and, potentially, tumor suppression. Experiments performed using 43 tumor-derived cell lines of different SNP309 genotypes gave strong support to this hypothesis, particularly by 
demonstrating that cells $\mathrm{G} / \mathrm{G}$ in genotype contain up to eightfold higher levels of MDM2 RNA and, on average, fourfold more MDM2 protein than cells $\mathrm{T} / \mathrm{T}$ in genotype. Moreover, four other cell lines $T / G$ in genotype for SNP309 were shown to contain intermediate protein levels (1.9-fold higher than $\mathrm{T} / \mathrm{T}$ cells) (Bond et al. 2004). Similar trends have subsequently been observed in other studies using tumor-derived cell lines (Bond et al. 2004; Arva et al. 2005; Hu et al. 2007a), renal cell carcinomas (Hirata et al. 2007), normal esophageal tissues (Hong et al. 2005), and B-cell chronic lymphocytic leukemias (Gryshchenko et al. 2008).

Together, these observations support a model whereby Sp1 binds to the G-allele of MDM2 SNP309 with greater affinity than the T-allele, resulting in heightened MDM2 levels and the attenuation of the $\mathrm{p} 53$ pathway-mediated tumor suppression (Bond et al. 2004). Importantly, evidence from patient populations has also lent support to this model (Vazquez et al. 2008). For example, in the initial study, p53 mutation carriers (Li-Fraumeni individuals) with the Gallele of MDM2 SNP309 were shown to be diagnosed with tumors on average 7 years earlier than those that were $\mathrm{T} / \mathrm{T}$ in genotype (Bond et al. 2004). This observation has been reproduced in three independent studies, in which p53 mutation carriers with the G-allele of MDM2 SNP309 were diagnosed with cancer on average $10,12.5$, and 16 years earlier than those who were homozygous for the T-allele (Bougeard et al. 2006; Ruijs et al. 2007; Marcel et al. 2009). Earlier ages of onset associated with individuals with the G-allele, but no known p53 mutations, were also shown in soft-tissue sarcomas (Bond et al. 2004), lymphoma (Bond et al. 2006a), leukemia (Swinney et al. 2005), head, neck and oral squamous cell carcinomas (Huang et al. 2009; Nakashima et al. 2008), and cancers of the colon (Menin et al. 2006), breast (Bond et al. 2006a; Wasielewski et al. 2006), bladder (Sanchez-Carbayo et al. 2007), ovary (Bartel et al. 2008), brain (Khatri et al. 2008), and liver (Yoon et al. 2008).

Subsequently, additional studies with sporadic cancers have shown that the effects of the
G-allele of MDM2 SNP309 locus on tumorigenesis can be modified by two additional variables; namely gender and the primarily female-specific hormone, estrogen (Alhopuro et al. 2005; Bond et al. 2006a; Bond et al. 2006b; Lind et al. 2006; Bond and Levine 2007). Specifically, the G-allele of MDM2 SNP309 was shown to accelerate tumorigenesis and increase cancer risk in women, but not in men for colorectal cancer, diffuse large B-cell lymphoma, lung cancer, and for highly estrogen receptor positive ( $>50 \%$ of tumor cells), but not for estrogen receptor negative, invasive ductal carcinoma of the breast (Bond et al. 2006a; Bond et al. 2006b; Lind et al. 2006). This was shown to result in the enrichment of individuals with the G-allele in premenopausal women with these cancers, when compared with either postmenopausal women or men with the same cancers. Subsequently, similar trends have been observed in melanoma and osteosarcoma patients (Firoz et al. 2009; Toffoli et al. 2009), whereas other studies suggest these trends will not be seen in every cancer and could be restricted to specific racial and ethnic backgrounds (Park et al. 2006; Bittenbring et al. 2008; Grochola et al. 2009).

Recently, Hu et al. provided evidence for a possible molecular mechanism for how the G-allele of SNP309 could accelerate tumor formation in this gender-specific and estrogen-dependent manner for some cancers, by demonstrating that the primarily female-specific hormone, estrogen, preferentially stimulated transcription of the MDM2 gene with the G-allele of SNP309 (Hu et al. 2007a). If correct, this model could offer a potential node of intervention for prevention and treatment of certain tumor types (Fig. 2). The model predicts that women with a G/G genotype for MDM2 SNP309 could be affected differently by estrogen signaling manipulation than women with a $\mathrm{T} / \mathrm{T}$ genotype. Specifically, increasing estrogen levels in postmenopausal women with a $\mathrm{G} / \mathrm{G}$ genotype, to alleviate menopausal symptoms, could significantly increase their risk to develop certain cancers. Furthermore, this model also predicts that women with a $\mathrm{G} / \mathrm{G}$ genotype and a high risk of cancer could benefit from decreasing 
L.F. Grochola et al.

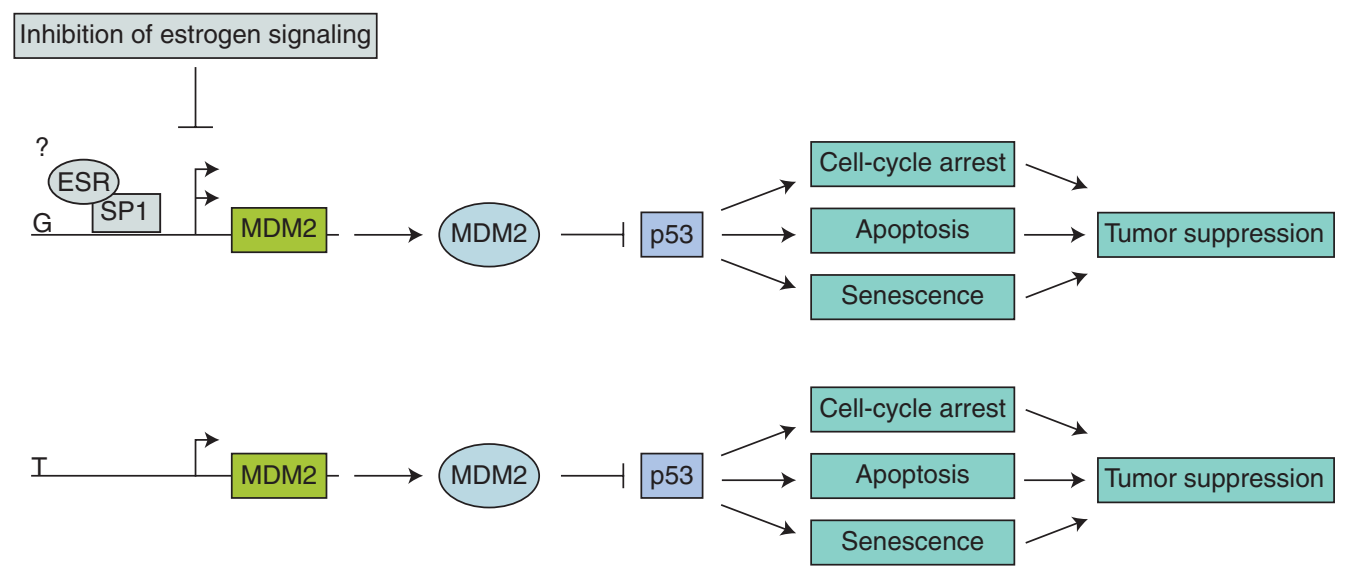

Figure 2. Individuals with different genotypes of MDM2 SNP309 could be affected differently by estrogen signaling manipulation. A model has been proposed that the primarily female-specific hormone, estrogen, preferentially stimulated transcription of the MDM2 gene with the G-allele of SNP309, potentially through the direct interaction of the estrogen receptor (ESR) and the transcription factor SP1 on the MDM2 promoter. If true, this predicts that inhibition of estrogen signaling in individuals with the G-allele of MDM2 SNP309 would lead to a reduction of MDM2 levels and a reactivation of p53 activity, allowing for either better tumor suppression or tumor clearance compared with individuals with the T-allele.

estrogen levels as could be relevant to p53 germline mutation carriers. Specifically, a recent study provided evidence that the G-allele of SNP309 functions primarily in female p53 mutation carriers to accelerate tumor formation (Atwal et al. 2008), which provided a potential genetic basis for a well-described sexual dimorphism in cancer risk observed in p53-mutation carriers (Chompret et al. 2000; Hwang et al. 2003). This finding in conjunction with the previously described observations provide a reasonable hypothesis; the G-allele of the MDM2 SNP309 locus could contribute to the increased cancer risk observed in female p53 mutation carriers through the preferential estrogendependent stimulation of transcription of the MDM2 gene. If true, this model predicts that estrogen reduction or withdrawal from G-allele MDM2 SNP309 patients could be incorporated in prevention strategies for p53-mutation carriers, for whom cancer prevention strategies are limited, much as they have been successfully implemented for BRCA-mutation carriers (Rebbeck et al. 1999; Narod et al. 2000; Gronwald et al. 2006).

\section{POTENTIAL FUNCTIONAL p53 PATHWAY SNPs}

\section{Caspase-8 D302H}

One important upstream effector of this extrinsic apoptotic pathway is caspase- 8 , which is activated after ligation of death receptors and initiates a cascade of downstream effector caspases (Bodmer et al. 2000; Hengartner 2000; Peter 2000). Recent evidence has shown that caspase- 8 is also directly regulated by p 53 under certain conditions, such as after cellular exposure to cytotoxic drugs (Ehrhardt et al. 2008). Recent studies have shown a positive-feedback loop between p53 and caspase-8 (Yao et al. 2007). The products of caspase- 8 cleavagedeath effector domains (DED) — can activate p53 to induce caspase-8 gene expression, which allows the continual replenishment of caspase- 8 during apoptosis (Yao et al. 2007). Furthermore, in transfection experiments, p53 has been shown to be able to directly regulate caspase-8 transcription through a p53-responsive sequence adjacent to the transcriptional start site of caspase-8 (Liedtke et al. 2003). 
Recently, an SNP in the caspase- 8 gene, termed D302H (rs1045485), has been reported to associate with altered breast cancer risk (MacPherson et al. 2004). This SNP results in an aspartic acid to histidine substitution at codon 302 of the gene, and is found at a high frequency in Europeans, with a minor allele frequency (MAF) of $20 \%$, but has not been reported in Asian and African populations (http://www.ncbi.nlm.nih.gov). The first study noted an association of the minor histidine-encoding allele ( $\mathrm{H}$-allele) of $\mathrm{D} 302 \mathrm{H}$ with reduced incidence of breast cancer in two independent cohorts in the United Kingdom (MacPherson et al. 2004). This finding was largely supported by two subsequent reports in a German population (Frank et al. 2005) and in a population in the United States (Sigurdson et al. 2007). Importantly, further supporting evidence of the protective role of the $\mathrm{H}$-allele of SNP D302H in breast cancer was provided in a large casecontrol study comprising multiple ethnic cohorts of mostly European ancestry, performed by the Breast Cancer Association Consortium (BCAC) (Cox et al. 2007). This study consisted of an analysis of 14 independent studies with a total of 16,423 cases and 17,109 controls. In line with these observations, in case-control studies of sporadic breast cancer, a significant 11-year delay of breast carcinoma onset has been reported for the $\mathrm{H}$-allele in a Spanish cohort of 390 patients carrying germ-line BRCA1/2 mutations (Palanca Suela et al. 2009). Similar associations were seen in a study conducted in chronic lymphocytic leukemia (Enjuanes et al. 2008). However, in contrast, no significant associations were seen in colon carcinoma (Pittman et al. 2008), and an inverse effect was reported for glioma, whereby the $\mathrm{H}$-allele of SNP D302H seems to associate with an increased risk for this malignancy (Bethke et al. 2008).

\section{p21 Codon 31}

The cyclin-dependent kinase (CDK) inhibitor p21 (CDKN1A) mediates the induction of cell-cycle arrest in response to a variety of stimuli, mainly through its ability to inhibit the kinase activity of CDK2 and CDK1 (Brugarolas et al. 1995; Deng et al. 1995; Macleod et al. 1995; Abbas and Dutta 2009). The role of p21 in promoting DNA damage-induced G1 growth arrest relies to a great extent on its welldescribed transcriptional activation by p53 (Macleod et al. 1995; Abbas and Dutta 2009). Given its crucial role in halting cellular proliferation, it is not surprising that p21 has been found to be frequently misregulated in human cancer, and the loss of its expression or function has been implicated in the genesis or progression of many human malignancies (Macleod et al. 1995; Abbas and Dutta 2009). However, other studies also suggest that p21 can promote cancer, indicating a paradoxical effect leading to tumor-suppressing or tumor-promoting properties of p21, depending on the cellular context (Rowland and Peeper 2006; Abukhdeir and Park 2008; Abbas and Dutta 2009).

The nonsynonymous codon 31 (C/A) SNP in the CDKN1A gene (rs1801270) results in an amino acid change from serine (p21-Ser) to arginine ( $\mathrm{p} 21-\mathrm{Arg}$ ) in a highly conserved region of the gene (Chedid et al. 1994). Similar to p53 codon72 and MDM2 SNP309, the allelic frequency at this locus varies greatly among populations, from a $4 \%$ prevalence of the Arg allele in a Swedish population to $50 \%$ in Chinese (Birgander et al. 1996). Functional studies seem to suggest that p21-Ser and p21-Arg variants share similar kinase inhibitory activity and growth suppression abilities (Sun et al. 1995). However, the different genetic alleles that encode these variants have been shown to differ significantly in their transcriptional efficiency (Su et al. 2003b; Johnson et al. 2009). Specifically, individuals who carry at least one p21-Arg-encoding allele associate with 38\% lower p21 mRNA expression (Su et al. 2003b). Similar observations were seen in a study designed to assess the role of the $\mathrm{p} 21$ codon 31 polymorphism in the ionizing radiation-induced, p53-dependent activation of p21 expression in chronic lymphocytic leukemia (Johnson et al. 
L.F. Grochola et al.

2009). The authors noted that cell lines harboring at least one p21-Arg-encoding allele showed an impaired p21 induction after radiation.

Possibly because of the seemingly conflicting reports linking p 21 overexpression to both cancer suppressive as well as promoting effects, studies exploring associations of p21 codon 31 and cancer susceptibility report different cancer risk alleles. Specifically, some studies support the idea that the p21-Arg-encoding allele associates with increased risk for lung (Sjalander et al. 1996), endometrial (Hachiya et al. 1999), cervical (Harima et al. 2001), bladder (Chen et al. 2002), head and neck (Rodrigues et al. 2003), and prostate cancers (Huang et al. 2004). In contrast, others studies reported a decreased risk associated with the p21-Arg-encoding allele for cervical (Roh et al. 2001), esophageal (Wu et al. 2003), and endometrial cancers (Roh et al. 2004). In addition, some studies reported no clinical associations with this locus (Su et al. 2003a).

p27 -79C/T

p27 (CDKN1B), another important CDK inhibitor, monitors $G_{0}$ to $S$ phase transitions by binding to and regulating the activity of various kinases involved in cell-cycle progression (Abukhdeir and Park 2008; Chu et al. 2008). Under conditions of cellular stresses, p27 integrates a variety of signal transduction pathways into a final proliferation checkpoint (Abukhdeir and Park 2008; Chu et al. 2008). Mouse models suggest that $\mathrm{p} 27$ collaborates with $\mathrm{p} 53$ to modulate the cell cycle and suppress tumorigenesis in a tissue-specific manner (Philipp-Staheli et al. 2004; Damo et al. 2005). For example, germline deletion of one or both alleles of p27 has been shown to accelerate tumor development and associated mortality in $\mathrm{p} 53$ null mice, indicating potent synergy between loss of p27 and p53 (Philipp-Staheli et al. 2004).

The minor allele of an SNP within the p27 gene (-79C/T; rs34330), a $\mathrm{C}$ to $\mathrm{T}$ transition located $5^{\prime}$ UTR at the site of nucleotide -79 , was first proposed to confer an increased risk of prostate carcinoma in a hereditary prostate cancer (HPC) family-based study conducted at the Johns Hopkins Hospital in Baltimore, Maryland (Chang et al. 2004). Subsequently, the minor allele was also shown to associate with an increased risk of breast cancer in a case-control study, which included 368 Chinese breast cancer cases and 467 cancer-free controls (Ma et al. 2006). Furthermore, another study conducted in a large British population comprising 4470 cases of breast carcinoma and 4560 controls provided further evidence of a statistically significant association of the minor allele of p27 -79C/T with increased cancer risk (Driver et al. 2008).

\section{p73 G4C14-to-A4T14}

p73 and p63 are two closely p53-related genes, which share a high level of sequence similarity with p53 and are capable of transactivating p53-responsive genes, thereby promoting cellcycle arrest and apoptosis (Benard et al. 2003; Murray-Zmijewski et al. 2006). Among the polymorphisms within the p73 gene, two common SNPs lie just upstream of the translational start site of exon 2 in so-called position 4 (G/A) and position $14(\mathrm{C} / \mathrm{T})$. These SNPs have been consistently shown to associate with allelic differences in risk for various cancers (Ryan et al. 2001; Li et al. 2004a; Li et al. 2004b; Hu et al. 2005; Niwa et al. 2005; Pfeifer et al. 2005; Chen et al. 2008; De Feo et al. 2009). They are in complete linkage disequilibrium with each other and therefore the alleles are always inherited together to form the so-called p73 G4C14-to-A4T14 polymorphism (Kaghad et al. 1997; Ryan et al. 2001). The minor allele of G4C14-to-A4T14, A4T14, has been shown to associate with a significantly increased risk for squamous cell carcinoma of the head and neck (Li et al. 2004a; Chen et al. 2008), gastric (De Feo et al. 2009), colorectal (Pfeifer et al. 2005), as well as endometrial cancers (Niwa et al. 2005). Consistent with these findings, a study conducted in the United States with 1054 non-Hispanic whites diagnosed with 
lung cancer and 1139 cancer-free controls reported an association of the A4T14 allele with increased cancer risk (Li et al. 2004b). However, the A4T14 allele was shown to associate with a decreased risk in lung cancer in a study comprised of 425 Chinese lung cancer patients and 588 cancer-free controls (Hu et al. 2005). Intriguingly, an apparently protective effect of A4T14 was reported in a small study comprising 84 esophageal carcinoma patients and 152 controls in Ireland (Ryan et al. 2001). Interestingly, two independent studies performed in Korean populations showed no significant allelic differences for p73 G4C14-to-A4T14 in lung cancer risk (Choi et al. 2006; Jun et al. 2007). Together, these observations suggest that the effects of p73 G4C14-to-A4T14 could be dependent on the ethnic background of the population studied.

\section{ATM Ser49Cys}

Another gene involved in the p53 stress response pathway is Ataxia telangiectasia mutated (ATM) (Kastan and Lim 2000; Levine et al. 2006). ATM is a serine/threonine-specific protein kinase that is activated by DNA doublestrand breaks (Kastan and Lim 2000). It phosphorylates several key proteins that initiate the activation of the DNA damage checkpoint, leading to cell-cycle arrest or apoptosis (Kastan and Lim 2000; Shiloh 2003). Current evidence suggests that p53 is the main target of ATM, which regulates the phosphorylation of p53 on Ser9, Ser15, Ser46, and Ser376, and subsequently impacts p53 transcriptional activity (Banin et al. 1998; Canman et al. 1998; Waterman et al. 1998; Ashcroft et al. 1999; Saito et al. 2002). Furthermore, ATM also activates the checkpoint kinase CHK2 and MDM2, proteins that directly regulate the activity of p53 (Khosravi et al. 1999; Bartek et al. 2001; Maya et al. 2001).

A low-frequency SNP in the ATM gene, mainly present in populations with European ancestry, results in a serine (Ser-ATM) to cysteine (Cys-ATM) substitution in codon 49 (ATM
Ser49Cys; rs1800054; MEF 3.3\%; http://www. ncbi.nlm.nih.gov) (Buchholz et al. 2004). ATM Ser49Cys has been shown by multiple studies to harbor allelic differences in breast cancer risk (Buchholz et al. 2004; Stredrick et al. 2006; Cox et al. 2007). The Cys-ATM-encoding allele of ATM Ser49Cys has been shown to associate with an increased risk of bilateral breast carcinoma in a report comprising two large populationbased studies from the United States and Poland, including a total of 2856 breast cancer patients and 3344 cancer-free controls (Stredrick et al. 2006). The results of a subsequent report suggest the increased risk associated with Cys-ATM is statistically significant, but only in a subset of progesterone receptor positive breast cancers (Cox et al. 2007). The prospective Copenhagen City Heart Study genotyped ATM Ser49Cys in 10324 individuals (Dombernowsky et al. 2008). Of those 10,324, 2,293 had developed various types of cancers. Interestingly, patients harboring Cys-ATM presented with an increased risk of melanoma, prostate carcinoma, and cancers of the oral cavity/pharynx, but not the breast (Dombernowsky et al. 2008). However, a stratification in patients according to the sex hormone receptor status was not performed, therefore a significant effect in the subset of patients with progesterone receptor-positive tumors cannot be excluded with certainty in this study.

\section{SCREENS THAT IDENTIFY POTENTIAL FUNCTIONAL p53 PATHWAY SNPS}

The previously described studies suggest that the p53 stress response pathway could harbor more functional inherited genetic variants, the study of which could help further define patient populations in their abilities to respond to stress, suppress tumor formation, and respond to DNA damaging therapies. The identification of functional SNPs that mediate the p53 stress response will prove challenging, as there are more than 50,000 SNPs in the NCBI SNP repository ( $\mathrm{dbSNP}$ ) in genes that have been implicated in mediating and regulating the p53 
L.F. Grochola et al.

response (Vazquez et al. 2008). However, recently, approaches have been described that could help identify potential functional p53 pathway SNPs (Tomso et al. 2005; Atwal et al. 2009; Grochola 2009; Noureddine et al. 2009; Smirnov et al. 2009). Specifically, these screens identify SNPs, or groups of linked SNPs (haplotypes), that demonstrate allelic differences in characteristics similar, but not limited to, functional p53 pathway SNPs.

Smirnov et al. presented an approach with the potential to identify SNPs that affect the cellular DNA-damage response (Smirnov et al. 2009). In this DNA-damage response screen, the authors analyze individual variation in gene expression in response to ionizing radiation and conduct genetic linkage and association studies to map their regulators, testing for evidence of an association of their measurements with multiple polymorphic loci (Smirnov et al. 2009). Briefly, the authors used microarray experiments to measure the gene expression levels in immortalized B cells from members of $15 \mathrm{CEPH}$ pedigrees, made up of 30 individuals, 2 and 6 hours after exposure to $10 \mathrm{~Gy}$ of ionizing radiation. Subsequently, a computational genome-wide linkage analysis for each of the gene expression phenotypes was performed linking those phenotypes to the genotypes of 4600 SNPs. As the p53 signaling pathway is important in the cellular responses to DNA damage and stress, one would reason that p53 pathway SNPs could be identified in this screen. Indeed, the authors identified novel SNPs in three p53 pathway associated genes (CD44, FAS, and PMAIP1), which were significantly associated with expression levels of their target genes (Smirnov et al. 2009).

A p53 pathway-oriented approach was designed to identify SNPs in potential p53 target genes that could affect the ability of p53 to regulate their transcription (Tomso et al. 2005; Noureddine et al. 2009). This approach first uses bioinformatics to scan for alleles of SNPs in p53 promoter response elements (REs) of potential p53 target genes that could modify p53 protein-DNA interactions. Subsequently, functional yeast and mammalian cell-based assays are undertaken to assess the predicted effects of the alleles on p53-dependent transactivation. This method has been recently refined to include a multiplex format microsphere assay to further probe how alleles affect p53 ability to bind its RE (Noureddine et al. 2009). Interestingly, this approach has identified eight p53 response elements in or adjacent to eight genes (ADAR2, ARHGEF7, DCC, EOMES, RRM1, SCGB1D2, SEI1, and TLR8), which harbor SNPs that significantly affect the cellular transactivation capabilities of p53 and its in vitro binding characteristics in nuclear extracts (Tomso et al. 2005; Noureddine et al. 2009). The biological and clinical relevance of these findings remains to be determined.

Two recent reports have looked for signatures of recent natural selection to identify genes in the p53 pathway that harbor functional SNPs (Atwal et al. 2009; Grochola 2009). These studies were motivated by the observation that the unusually long and frequent haplotype that harbors the G-allele of MDM2 SNP309 deviates significantly from the standard assumptions of selective neutrality using multiple selection tests (Atwal et al. 2007). This suggested that the human p53 pathway could be acted on by an evolutionary selection pressure. Although the precise reason(s) for the selection pressure on the $\mathrm{p} 53$ pathway is still under investigation (Kay et al. 2006; Atwal et al. 2007; Hu et al. 2007b; Fang et al. 2009; Firouzabadi et al. 2009; Kang et al. 2009), the authors reasoned that other SNPs in the $\mathrm{p} 53$ pathway with signatures of natural selection might also affect p53 signaling and affect cancer in humans (Atwal et al. 2009; Grochola 2009). In these two reports, a total of 142 genes that affect p53 signaling were analyzed, and signs of recent natural selection were found in the haplotype distributions of the MDM4 oncogene and the PPP2R5E gene, a regulatory subunit of protein phosphatase 2 A (PP2A). Importantly, for both genes, the selected haplotypes were shown to associate with clinical differences in human cancer compared with the neutral haplotypes (Atwal et al. 2009; Grochola 
2009). For example, for the MDM4 oncogene, the neutral haplotypes were identified as being associated with a greater risk of developing breast tumors in three independent populations of Ashkenazi Jewish Caucasians, and developing ovarian tumors up to 9 years earlier in life in both familial and sporadic ovarian cancer in non-Ashkenazi Jewish Caucasian cohorts (Atwal et al. 2009). These observations suggest that, like MDM2, MDM4 and PPP2R5E harbor SNPs that affect cancer in humans.

In summary, a large body of evidence suggests that the p53 stress response pathway harbors functional inherited SNPs that affect p53 signaling in cells, resulting in differences in cancer risk and clinical outcome in humans. Multiple genes that encode proteins important in p53-mediated signal transduction have been shown to harbor SNPs that consistently associate with allelic differences in human cancer (Fig. 3) (Table 1). Moreover, recent screens to identify novel functional p53 pathway SNPs suggest that many more are yet to be fully characterized, and the potentially significant, combined effects of these functional SNPs on cancer-related phenotypical manifestations, could strongly enhance the use of germline genetics in everyday clinical practice. Indeed, the more detailed characterization of the molecular mechanisms behind the clinically relevant SNPs in p53 and MDM2 has offered insights into how the genetic information could be translated into the clinic. This work suggests that a thorough analysis of the functional human genetics of this important tumor suppressor pathway is required and could result in the tailoring of current therapies to the individu$\mathrm{al}$, as well as in a deeper understanding of the role of p53 signaling in humans.

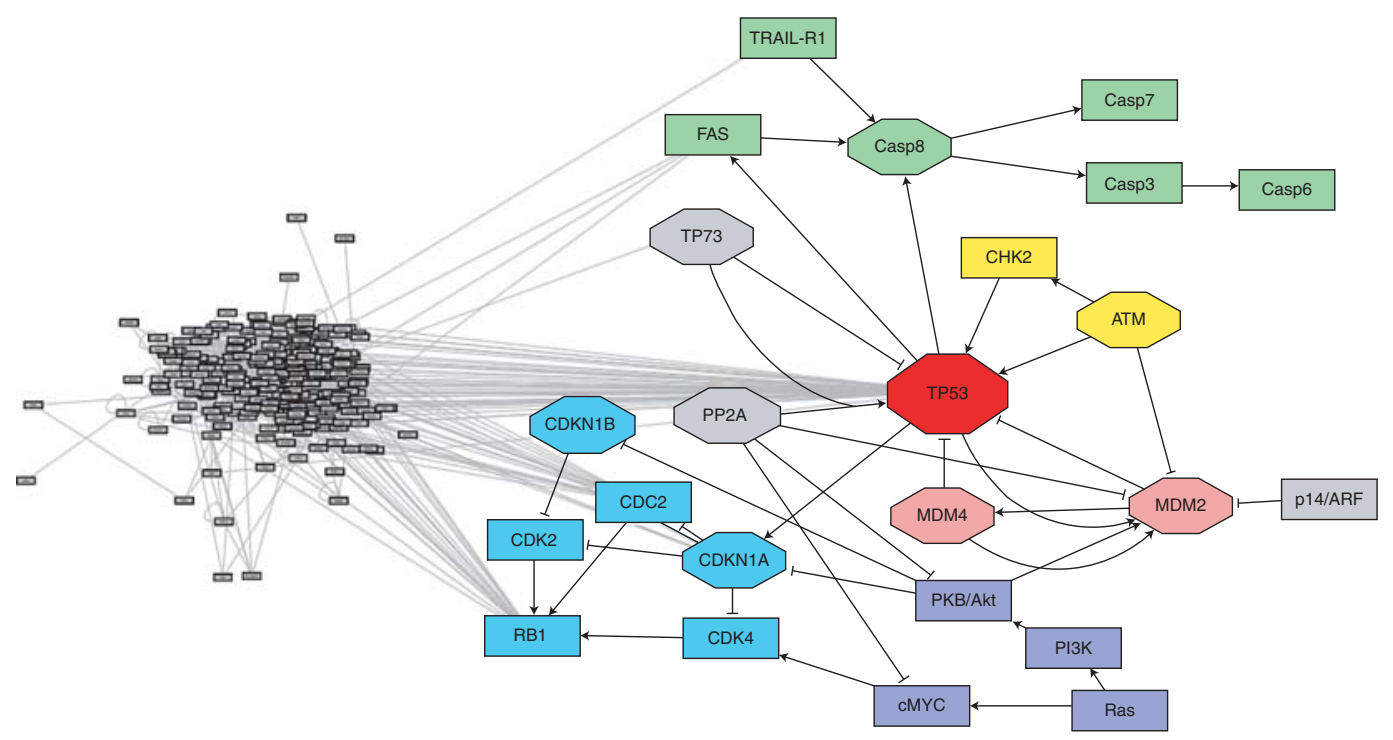

Figure 3. Map of selected p53 pathway-associated genes that harbor known or potential functional SNPs (octagon-shaped boxes) and their closely interacting genes (rectangular boxes). The map depicts genes involved in the core regulation of p53 (light red boxes), the DNA-damage response (yellow), the extrinsic apoptotic response (green), the cell-cycle (turquoise) and oncogenic signaling (dark blue). The arrows $(\downarrow)$ show downstream activation and the inhibitory interactions are delineated by T-shaped $(\perp)$ ends. A network map representing the p53 pathway is illustrated in the distant background. 


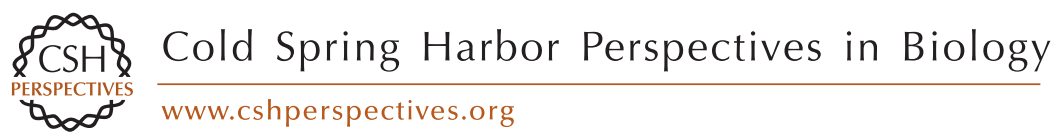

Table 1. Clinically Relevant Single-nucleotide Polymorphisms in the p53 Pathway

\begin{tabular}{|c|c|c|c|c|c|c|}
\hline \multicolumn{3}{|c|}{ Gene } & \multicolumn{4}{|c|}{ SNP } \\
\hline $\begin{array}{l}\text { Hugo } \\
\text { name }\end{array}$ & Function & $\begin{array}{c}\text { Association with the p53 } \\
\text { pathway }\end{array}$ & Description & $\begin{array}{l}\mathrm{db} \text { SNP } \\
\text { rs\#ID }\end{array}$ & Clinical association & Molecular description \\
\hline TP53 & $\begin{array}{l}\text { Tumor suppressor; functions } \\
\text { as transcription factor, } \\
\text { responds to diverse cellular } \\
\text { stresses. Regulates target } \\
\text { genes that induce cell-cycle } \\
\text { arrest, apoptosis, } \\
\text { senescence, DNA repair, or } \\
\text { changes in metabolism. }\end{array}$ & $\begin{array}{l}\text { Central node of the p53 } \\
\text { pathway. }\end{array}$ & P53 codon72 & rs 1042522 & $\begin{array}{l}\text { Many examples, such as } \\
\text { allelic differences in } \\
\text { response to } \\
\text { chemotherapeutic } \\
\text { treatment of head and } \\
\text { neck carcinomas. }\end{array}$ & $\begin{array}{l}\text { Proline to arginine residue } \\
\text { change in a region } \\
\text { important in mediating } \\
\text { the apoptotic response } \\
\text { affects the level of } \\
\text { apoptosis. }\end{array}$ \\
\hline MDM2 & $\begin{array}{l}\text { Key negative regulator of the } \\
\text { p53 protein. }\end{array}$ & $\begin{array}{l}\text { Transcriptional target of } \\
\text { p53; Inhibits p53 activity } \\
\text { by binding the } \\
\text { transactivation domain of } \\
\text { the p53 protein and } \\
\text { promoting its } \\
\text { ubiquitination as well as } \\
\text { regulating its cellular } \\
\text { location. }\end{array}$ & MDM2 SNP309 & rs2279744 & $\begin{array}{l}\text { Increased risk for and } \\
\text { earlier age of onset of } \\
\text { various cancer types, } \\
\text { particularly in younger } \\
\text { females }\end{array}$ & $\begin{array}{l}\mathrm{T} \text { to G change in the } \\
\text { promoter region of } \\
\text { intron } 1 \text { results in an } \\
\text { enhanced binding } \\
\text { affinity of the } \\
\text { transcription factor SP1 } \\
\text { and increased MDM2 } \\
\text { gene transcription }\end{array}$ \\
\hline Casp8 & $\begin{array}{l}\text { An upstream protease of the } \\
\text { activation cascade of } \\
\text { caspases responsible for the } \\
\text { death receptor induced } \\
\text { apoptosis. }\end{array}$ & $\begin{array}{l}\text { TP53 activates caspase } 8 \text { gene } \\
\text { expression after induction } \\
\text { by death effector domains } \\
\text { or exposure to cytotoxic } \\
\text { drugs. Positive-feedback } \\
\text { loop with p53. }\end{array}$ & D302H & rs 1045485 & $\begin{array}{l}\text { Minor allele associates } \\
\text { with reduced incidence } \\
\text { of breast cancer. }\end{array}$ & $\begin{array}{l}\text { Aspartic acid to histidine } \\
\text { substitution in codon } \\
302 \text {. }\end{array}$ \\
\hline ATM & $\begin{array}{l}\text { Serine/threonine protein } \\
\text { kinase, which activates } \\
\text { checkpoint signaling upon } \\
\text { genotoxic stresses. }\end{array}$ & $\begin{array}{l}\text { Regulates the } \\
\text { phosphorylation of p53 on } \\
\text { various residues and } \\
\text { activates MDM2 as well as }\end{array}$ & ATM Ser49Cys & rs 1800054 & $\begin{array}{l}\text { Minor allele suggested to } \\
\text { associate with increased } \\
\text { cancer risk, particularly } \\
\text { breast carcinoma. }\end{array}$ & $\begin{array}{l}\text { Serine to cystein } \\
\text { substitution in codon } \\
49 .\end{array}$ \\
\hline
\end{tabular}

transactivation domain of

drugs. Positive-feedback

oop with p53.

activates MDM2 as well as

the checkpoint kinase

CHK2. 
CDKN1A Binds and inhibits the activity Tightly controlled by p53, of cyclin-dependent kinases, and thus functions as a regulator of cell-cycle progression at $\mathrm{G} 1$.

CDKN1B Cyclin-dependent kinase inhibitor; binds to an prevents the activation of cyclin E-CDK2 or cyclin D-CDK4 complexes, and thus controls the cell cycle at $\mathrm{G} 1$.

TP73

mediates the

p53-dependent cell cycle

to a variety of stress

$$
\text { stimuli. }
$$

Collaborates with p53 to suppress tumorigenesis. through which this protein

G1 phase arrest in response

$-79 \mathrm{C} / \mathrm{T}$

modulate the cell cycle and

p21 codon 31 ember of p53 family of transcription factors, involved in cellular responses to stress and development.

.

TP73 transactivates p53-responsive genes causing cell-cycle arrest and apoptosis; some isoforms can directly inhibit p53 function.
G4C14-to-A4T14 rs2273953 Allelic differences for rs1801173 various cancer types.
Serine to arginine substitution in a highly conserved region of the gene; alleles suggested to differ in transcriptional efficiency.

C to T transition $5^{\prime}$ UTR at the site of nucleotide -79 breast cancer.

Two linked intronic SNPs, just upstream of the

initiating AUG of exon 2 in position 4 and 14 of the gene 
L.F. Grochola et al.

\section{REFERENCES}

Abbas T, Dutta A. 2009. p21 in cancer: Intricate networks and multiple activities. Nat Rev Cancer 9: 400-414.

Abukhdeir AM, Park BH. 2008. P21 and p27: Roles in carcinogenesis and drug resistance. Expert Rev Mol Med 10: e19.

Alhopuro P, Ylisaukko-Oja SK, Koskinen WJ, Bono P, Arola J, Jarvinen HJ, Mecklin JP, Atula T, Kontio R, Makitie AA, et al. 2005. The MDM2 promoter polymorphism SNP309T $->\mathrm{G}$ and the risk of uterine leiomyosarcoma, colorectal cancer, and squamous cell carcinoma of the head and neck. J Med Gen 42: 694-698.

Arva NC, Gopen TR, Talbott KE, Campbell LE, Chicas A, White DE, Bond GL, Levine AJ, Bargonetti J. 2005. A chromatin-associated and transcriptionally inactive p53-Mdm2 complex occurs in mdm2 SNP309 homozygous cells. J Biol Chem 280: 26776-26787.

Ashcroft M, Kubbutat MH, Vousden KH. 1999. Regulation of p53 function and stability by phosphorylation. Molecular Cell Biol 19: 1751-1758.

Atwal GS, Bond GL, Metsuyanim S, Papa M, Friedman E, Distelman-Menachem T, Ben Asher E, Lancet D, Ross DA, Sninsky J, White TJ, et al. 2007. Haplotype structure and selection of the MDM2 oncogene in humans. Proc Natl Acad Sci 104: 4524-4529.

Atwal GS, Rabadan R, Lozano G, Strong LC, Ruijs MW, Schmidt MK, Van't Veer LJ, Nevanlinna H, Tommiska J, Aittomaki K, et al. 2008. An information-theoretic analysis of genetics, gender and age in cancer patients. PLoS One 3: e1951.

Atwal GS, Kirchhoff T, Bond EE, Monagna M, Menin C, Bertorelle R, Scaini MC, Bartel F, Bohnke A, Pempe C, et al. 2009. Altered tumor formation and evolutionary selection of genetic variants in the human MDM4 oncogene. Proc Natl Acad Sci 106: 10236-10241.

Banin S, Moyal L, Shieh S, Taya Y, Anderson CW, Chessa L, Smorodinsky NI, Prives C, Reiss Y, Shiloh Y, Ziv Y. 1998. Enhanced phosphorylation of $\mathrm{p} 53$ by ATM in response to DNA damage. Science 281: 1674-1677.

Bartek J, Falck J, Lukas J. 2001. CHK2 kinase-a busy messenger. Nat Rev Mol Cell Biol 2: 877-886.

Bartel F, Jung J, Bohnke A, Gradhand E, Zeng K, Thomssen C, Hauptmann S. 2008. Both germ line and somatic genetics of the p53 pathway affect ovarian cancer incidence and survival. Clin Cancer Res 14: 89-96.

Benard J, Douc-Rasy S, Ahomadegbe JC. 2003. TP53 family members and human cancers. Human Mutation 21: 182-191.

Bergamaschi D, Gasco M, Hiller L, Sullivan A, Syed N, Trigiante G, Yulug I, Merlano M, Numico G, Comino A, et al. 2003. p53 polymorphism influences response in cancer chemotherapy via modulation of p73-dependent apoptosis. Cancer Cell 3: 387-402.

Bergamaschi D, Samuels Y, Sullivan A, Zvelebil M, Breyssens H, Bisso A, Del Sal G, Syed N, Smith P, Gasco M, et al. 2006. iASPP preferentially binds p53 proline-rich region and modulates apoptotic function of codon 72-polymorphic p53. Nat Gen 38: 1133-1141.

Bethke L, Sullivan K, Webb E, Murray A, Schoemaker M, Auvinen A, Kiuru A, Salminen T, Johansen C, Christen- sen HC, et al. 2008. The common D302H variant of CASP8 is associated with risk of glioma. Cancer Epidemiol Biomarkers Prev 17: 987-989.

Birgander R, Sjalander A, Saha N, Spitsyn V, Beckman L, Beckman G. 1996. The codon 31 polymorphism of the p53-inducible gene p21 shows distinct differences between major ethnic groups. Human Heredity 46: $148-154$.

Bittenbring J, Parisot F, Wabo A, Mueller M, Kerschenmeyer L, Kreuz M, Truemper L, Landt O, Menzel A, Pfreundschuh M, Roemer K. 2008. MDM2 gene SNP309 T/G and 553 gene SNP72 G/C do not influence diffuse large B-cell non-Hodgkin lymphoma onset or survival in central European Caucasians. BMC Cancer 8: 116.

Bodmer JL, Holler N, Reynard S, Vinciguerra P, Schneider P, Juo P, Blenis J, Tschopp J. 2000. TRAIL receptor-2 signals apoptosis through FADD and caspase-8. Nat Cell Biol 2: 241-243.

Bonafe M, Salvioli S, Barbi C, Mishto M, Trapassi C, Gemelli C, Storci G, Olivieri F, Monti D, Franceschi C. 2002. p53 codon 72 genotype affects apoptosis by cytosine arabinoside in blood leukocytes. Biochem Biophys Res Commun 299: 539-541.

Bond GL, Levine AJ. 2007. A single nucleotide polymorphism in the p53 pathway interacts with gender, environmental stresses and tumor genetics to influence cancer in humans. Oncogene 26: 1317-1323.

Bond GL, Hirshfield KM, Kirchhoff T, Alexe G, Bond EE, Robins H, Bartel F, Taubert H, Wuerl P, Hait W, et al. 2006a. MDM2 SNP309 Accelerates Tumor Formation in a Gender-Specific and Hormone-Dependent Manner. Cancer Res 66: 5104-5110.

Bond GL, Hu W, Bond EE, Robins H, Lutzker SG, Arva NC, Bargonetti J, Bartel F, Taubert H, Wuerl P, et al. 2004. A single nucleotide polymorphism in the MDM2 promoter attenuates the $\mathrm{p} 53$ tumor suppressor pathway and accelerates tumor formation in humans. Cell 119: 591-602.

Bond GL, Menin C, Bertorelle R, Alhopuro P, Aaltonen LA, Levine AJ. 2006b. MDM2 SNP309 accelerates colorectal tumour formation in women. J Med Gen 43: 950-952.

Bougeard G, Baert-Desurmont S, Tournier I, Vasseur S, Martin C, Brugieres L, Chompret A, Bressac-de Paillerets B, Stoppa-Lyonnet D, Bonaiti-Pellie C, et al. 2006. Impact of the MDM2 SNP309 and p53 Arg72Pro polymorphism on age of tumour onset in Li-Fraumeni syndrome. J Med Gen 43: 531-533.

Brugarolas J, Chandrasekaran C, Gordon JI, Beach D, Jacks T, Hannon GJ. 1995. Radiation-induced cell cycle arrest compromised by p21 deficiency. Nature 377: 552-557.

Buchholz TA, Weil MM, Ashorn CL, Strom EA, Sigurdson A, Bondy M, Chakraborty R, Cox JD, McNeese MD Story MD. 2004. A Ser49Cys variant in the ataxia telangiectasia, mutated, gene that is more common in patients with breast carcinoma compared with population controls. Cancer 100: 1345-1351.

Buchman VL, Chumakov PM, Ninkina NN, Samarina OP, Georgiev GP. 1988. A variation in the structure of the protein-coding region of the human p53 gene. Gene 70: $245-252$.

Canman CE, Lim DS, Cimprich KA, Taya Y, Tamai K, Sakaguchi K, Appella E, Kastan MB, Siliciano JD. 1998. 
Activation of the ATM kinase by ionizing radiation and phosphorylation of p53. Science 281: 1677-1679.

Chang BL, Zheng SL, Isaacs SD, Wiley KE, Turner A, Li G, Walsh PC, Meyers DA, Isaacs WB, Xu J. 2004. A polymorphism in the CDKN1B gene is associated with increased risk of hereditary prostate cancer. Cancer Res 64: 1997-1999.

Chedid M, Michieli P, Lengel C, Huppi K, Givol D. 1994. A single nucleotide substitution at codon 31 (Ser/Arg) defines a polymorphism in a highly conserved region of the p53-inducible gene WAF1/CIP1. Oncogene 9: 3021-3024.

Chen X, Sturgis EM, Etzel CJ, Wei Q, Li G. 2008. p73 G4C14-to-A4T14 polymorphism and risk of human papillomavirus-associated squamous cell carcinoma of the oropharynx in never smokers and never drinkers. Cancer 113: 3307-3314.

Chen WC, Wu HC, Hsu CD, Chen HY, Tsai FJ. 2002. p21 gene codon 31 polymorphism is associated with bladder cancer. Urologic Oncol 7: 63-66.

Choi JE, Kang HG, Chae MH, Kim EJ, Lee WK, Cha SI, Kim $\mathrm{CH}$, Jung TH, Park JY. 2006. No association between p73 G4C14-to-A4T14 polymorphism and the risk of lung cancer in a Korean population. Biochem Gen 44: 543-550.

Chompret A, Brugieres L, Ronsin M, Gardes M, DessarpsFreichey F, Abel A, Hua D, Ligot L, Dondon MG, Bressac-de Paillerets B, et al. 2000. P53 germline mutations in childhood cancers and cancer risk for carrier individuals. Br J Cancer 82: 1932-1937.

Chu IM, Hengst L, Slingerland JM. 2008. The Cdk inhibitor p27 in human cancer: Prognostic potential and relevance to anticancer therapy. Nat Rev Cancer 8: 253-267.

Cox A, Dunning AM, Garcia-Closas M, Balasubramanian S, Reed MW, Pooley KA, Scollen S, Baynes C, Ponder BA, Chanock S, et al. 2007. A common coding variant in CASP8 is associated with breast cancer risk. Nature Gen 39: $352-358$.

Damo LA, Snyder PW, Franklin DS. 2005. Tumorigenesis in p27/p53- and p18/p53-double null mice: Functional collaboration between the $\mathrm{pRb}$ and $\mathrm{p} 53$ pathways. $\mathrm{Mol}$ Carcinogenesis 42: 109-120.

De Feo E, Persiani R, La Greca A, Amore R, Arzani D, Rausei S, D’Ugo D, Magistrelli P, van Duijn CM, Ricciardi G, et al. 2009. A case-control study on the effect of p53 and p73 gene polymorphisms on gastric cancer risk and progression. Mutation Res 675: 60-65.

Deng C, Zhang P, Harper JW, Elledge SJ, Leder P. 1995. Mice lacking p21CIP1/WAF1 undergo normal development, but are defective in G1 checkpoint control. Cell 82: 675-684.

Dombernowsky SL, Weischer M, Allin KH, Bojesen SE, Tybjaerg-Hansen A, Nordestgaard BG. 2008. Risk of cancer by ATM missense mutations in the general population. J Clin Oncol 26: 3057-3062.

Driver KE, Song H, Lesueur F, Ahmed S, Barbosa-Morais NL, Tyrer JP, Ponder BA, Easton DF, Pharoah PD, Dunning AM. 2008. Association of single-nucleotide polymorphisms in the cell cycle genes with breast cancer in the British population. Carcinogenesis 29: 333-341.

Dumont P, Leu JI, Della Pietra AC, George DL 3rd, Murphy M. 2003. The codon 72 polymorphic variants of $\mathrm{p} 53$ have markedly different apoptotic potential. Nat Gen 33: $357-365$.

Ehrhardt H, Hacker S, Wittmann S, Maurer M, Borkhardt A, Toloczko A, Debatin KM, Fulda S, Jeremias I. 2008. Cytotoxic drug-induced, p53-mediated upregulation of caspase-8 in tumor cells. Oncogene 27: 783-793.

Enjuanes A, Benavente Y, Bosch F, Martin-Guerrero I, Colomer D, Perez-Alvarez S, Reina O, Ardanaz MT, Jares P, Garcia-Orad A, et al. 2008. Genetic variants in apoptosis and immunoregulation-related genes are associated with risk of chronic lymphocytic leukemia. Cancer Res 68: $10178-10186$.

Fang Y, Kong B, Yang Q, Ma D, Qu X. 2009. MDM2 309 polymorphism is associated with missed abortion. $\mathrm{Hu}$ man Reproduction 24: 1346-1349.

Firouzabadi RD, Ghasemi N, Rozbahani MA, Tabibnejad N . 2009. Association of p53 polymorphism with ICSI/IVF failure and recurrent pregnancy loss. Austral $\mathrm{N}$ Zeal J Obstet Gynaecol 49: 216-219.

Firoz EF, Warycha M, Zakrzewski J, Pollens D, Wang G, Shapiro R, Berman R, Pavlick A, Manga P, Ostrer H, et al. 2009. Association of MDM2 SNP309, age of onset, and gender in cutaneous melanoma. Clin Cancer Res 15: 2573-2580.

Frank B, Bermejo JL, Hemminki K, Klaes R, Bugert P, Wappenschmidt B, Schmutzler RK, Burwinkel B. 2005. Re: Association of a common variant of the CASP8 gene with reduced risk of breast cancer. J Natl Cancer Inst 97: 1012; author reply 1012-1013.

Grochola LF, Müller TH, Bond GL, Taubert H, Udelnow A, Würl P. 2009. MDM2 SNP309 associates with accelerated pancreatic adenocarcinoma formation. Pancreas doi: 10.1097/MPA.0b013e3181b9f105.

Grochola LF, Vazquez A, Bond EE, Würl P, Taubert H, Müller TH, Levine AJ, Bond GL. 2009. Recent natural selection identifies a genetic variant in a regulatory subunit of protein phosphatase $2 \mathrm{~A}$ that associates with altered cancer risk and survival. Clin Cancer Res 15: 6301-6308.

Gronwald J, Tung N, Foulkes WD, Offit K, Gershoni R, Daly M, Kim-Sing C, Olsson H, Ainsworth P, Eisen A, et al. 2006. Tamoxifen and contralateral breast cancer in BRCA1 and BRCA2 carriers: An update. Int $J$ Cancer 118: $2281-2284$.

Gryshchenko I, Hofbauer S, Stoecher M, Daniel PT, Steurer M, Gaiger A, Eigenberger K, Greil R, Tinhofer I. 2008. MDM2 SNP309 is associated with poor outcome in B-cell chronic lymphocytic leukemia. J Clin Oncol 26: 2252-2257.

Hachiya T, Kuriaki Y, Ueoka Y, Nishida J, Kato K, Wake N. 1999. WAF1 genotype and endometrial cancer susceptibility. Gynecol Oncol 72: 187-192.

Harima Y, Sawada S, Nagata K, Sougawa M, Ostapenko V, Ohnishi T. 2001. Polymorphism of the WAF1 gene is related to susceptibility to cervical cancer in Japanese women. Int J Mol Med 7: 261-264.

Harris N, Brill E, Shohat O, Prokocimer M, Wolf D, Arai N, Rotter V. 1986. Molecular basis for heterogeneity of the human p53 protein. Mol Cell Biol 6: 4650-4656.

Haupt S, Haupt Y. 2006. Importance of p53 for cancer onset and therapy. Anticancer Drugs 17: 725-732.

Haupt Y, Maya R, Kazaz A, Oren M. 1997. Mdm2 promotes the rapid degradation of p53. Nature 387: 296-299. 
L.F. Grochola et al.

Hengartner MO. 2000. The biochemistry of apoptosis. $\mathrm{Na}$ ture 407: 770-776.

Hirata H, Hinoda Y, Kikuno N, Kawamoto K, Suehiro Y, Tanaka Y, Dahiya R. 2007. MDM2 SNP309 Polymorphism as risk factor for susceptibility and poor prognosis in renal cell carcinoma. Clin Cancer Res 13: 4123-4129.

Hong Y, Miao X, Zhang X, Ding F, Luo A, Guo Y, Tan W, Liu Z, Lin D. 2005. The role of P53 and MDM2 polymorphisms in the risk of esophageal squamous cell carcinoma. Cancer Res 65: 9582-9587.

Hu W, Feng Z, Ma L, Wagner J, Rice JJ, Stolovitzky G, Levine AJ. 2007a. A single nucleotide polymorphism in the MDM2 gene disrupts the oscillation of p53 and MDM2 levels in cells. Cancer Res 67: 2757-2765.

Hu W, Feng Z, Teresky AK, Levine AJ. 2007b. p53 regulates maternal reproduction through LIF. Nature 450: $721-724$.

Hu Z, Jin G, Wang L, Chen F, Wang X, Shen H. 2007c. MDM2 promoter polymorphism SNP309 contributes to tumor susceptibility: Evidence from 21 case-control studies. Cancer Epidemiol Biomarkers Prev 16: 27172723.

Hu Z, Miao X, Ma H, Tan W, Wang X, Lu D, Wei Q, Lin D, Shen H. 2005. Dinucleotide polymorphism of $\mathrm{p} 73$ gene is associated with a reduced risk of lung cancer in a Chinese population. Int J Cancer 114: 455-460.

Huang SF, Chen IH, Liao CT, Wang HM, Liou SH, Hsieh LL. 2009. Combined effects of MDM2 SNP 309 and p53 mutation on oral squamous cell carcinomas associated with areca quid chewing. Oral Oncol 45: 16-22.

Huang SP, Wu WJ, Chang WS, Wu MT, Chen YY, Chen YJ, Yu CC, Wu TT, Lee YH, Huang JK, Huang CH. 2004. p53 Codon 72 and $\mathrm{p} 21$ codon 31 polymorphisms in prostate cancer. Cancer Epidemiol Biomarkers Prev 13: 22172224.

Hwang SJ, Lozano G, Amos CI, Strong LC. 2003. Germline p53 mutations in a cohort with childhood sarcoma: Sex differences in cancer risk. Am J Hum Genet 72: 975-983.

Johnson GG, Sherrington PD, Carter A, Lin K, Liloglou T, Field JK, Pettitt AR. 2009. A novel type of p53 pathway dysfunction in chronic lymphocytic leukemia resulting from two interacting single nucleotide polymorphisms within the p21 gene. Cancer Res 69: 5210-5217.

Johnstone RW, Ruefli AA, Lowe SW. 2002. Apoptosis: A link between cancer genetics and chemotherapy. Cell 108: 153-164.

Jun HJ, Park SH, Lee WK, Choi JE, Jang JS, Kim EJ, Cha SI, Kim DS, Kam S, Kim CH, et al. 2007. Combined effects of p73 and MDM2 polymorphisms on the risk of lung cancer. Mol Carcinogenesis 46: 100-105.

Kaghad M, Bonnet H, Yang A, Creancier L, Biscan JC, Valent A, Minty A, Chalon P, Lelias JM, Dumont X, et al. 1997. Monoallelically expressed gene related to p53 at 1 p36, a region frequently deleted in neuroblastoma and other human cancers. Cell 90: 809-819.

Kang HJ, Feng Z, Sun Y, Atwal G, Murphy ME, Rebbeck TR, Rosenwaks Z, Levine AJ, Hu W. 2009. Single-nucleotide polymorphisms in the p53 pathway regulate fertility in humans. Proc Natl Acad Sci 106: 9761-9766.

Kastan MB, Lim DS. 2000. The many substrates and functions of ATM. Nat Rev Mol Cell Biol 1: 179-186.
Kay C, Jeyendran RS, Coulam CB. 2006. p53 tumour suppressor gene polymorphism is associated with recurrent implantation failure. Reproductive Biomed Online 13: 492-496.

Khatri RG, Navaratne K, Weil RJ. 2008. The role of a single nucleotide polymorphism of MDM2 in glioblastoma multiforme. J Neurosurg 109: 842-848.

Khosravi R, Maya R, Gottlieb T, Oren M, Shiloh Y, Shkedy D. 1999. Rapid ATM-dependent phosphorylation of MDM2 precedes p53 accumulation in response to DNA damage. Proc Natl Acad Sci 96: 14973-14977.

Lane DP. 2005. Exploiting the p53 pathway for the diagnosis and therapy of human cancer. Cold Spring Harb Symp Quant Biol 70: 489-497.

Levine AJ. 1997. p53, the cellular gatekeeper for growth and division. Cell 88: 323-331.

Levine AJ, Hu W, Feng Z. 2006. The P53 pathway: What questions remain to be explored? Cell Death and Differentiation 13: 1027-1036.

Li G, Sturgis EM, Wang LE, Chamberlain RM, Amos CI, Spitz MR, El-Naggar AK, Hong WK, Wei Q. 2004a. Association of a p73 exon 2 G4C14-to-A4T14 polymorphism with risk of squamous cell carcinoma of the head and neck. Carcinogenesis 25: 1911-1916.

Li G, Wang LE, Chamberlain RM, Amos CI, Spitz MR, Wei Q. 2004b. p73 G4C14-to-A4T14 polymorphism and risk of lung cancer. Cancer Res 64: 6863-6866.

Liedtke C, Groger N, Manns MP, Trautwein C. 2003. The human caspase- 8 promoter sustains basal activity through SP1 and ETS-like transcription factors and can be upregulated by a p53-dependent mechanism. J Biol Chem 278: 27593-27604.

Lind H, Zienolddiny S, Ekstrom PO, Skaug V, Haugen A. 2006. Association of a functional polymorphism in the promoter of the MDM2 gene with risk of nonsmall cell lung cancer. Int J Cancer 119: 718-721.

Lozano G, Zambetti GP. 2005. What have animal models taught us about the p53 pathway? J Pathol 205: 206-220.

Ma H, Jin G, Hu Z, Zhai X, Chen W, Wang S, Wang X, Qin J, Gao J, Liu J, Wang X, Wei Q, Shen H. 2006. Variant genotypes of CDKN1A and CDKN1B are associated with an increased risk of breast cancer in Chinese women. Int $J$ Cancer 119: 2173-2178.

Macleod KF, Sherry N, Hannon G, Beach D, Tokino T, Kinzler K, Vogelstein B, Jacks T. 1995. p53-dependent and independent expression of p21 during cell growth, differentiation, and DNA damage. Genes Develop 9: 935-944.

MacPherson G, Healey CS, Teare MD, Balasubramanian SP, Reed MW, Pharoah PD, Ponder BA, Meuth M, Bhattacharyya NP, Cox A. 2004. Association of a common variant of the CASP8 gene with reduced risk of breast cancer. J Natl Cancer Inst 96: 1866-1869.

Marcel V, Palmero EI, Falagan-Lotsch P, Martel-Planche G, Ashton-Prolla P, Olivier M, Brentani RR, Hainaut P, Achatz MI. 2009. TP53PIN3 and MDM2 SNP309 polymorphisms as genetic modifiers in the Li-Fraumeni syndrome: Impact on age at first diagnosis. J Med Gen 46: 766-772.

Marin MC, Jost CA, Brooks LA, Irwin MS, O’Nions J, Tidy JA, James N, McGregor JM, Harwood CA, Yulug IG, et al. 
2000. A common polymorphism acts as an intragenic modifier of mutant p53 behaviour. Nat Gen 25: 47-54.

Maya R, Balass M, Kim ST, Shkedy D, Leal JF, Shifman O, Moas M, Buschmann T, Ronai Z, Shiloh Y, et al. 2001. ATM-dependent phosphorylation of Mdm2 on serine 395: Role in 553 activation by DNA damage. Genes Develop 15: 1067-1077.

Mendrysa SM, O'Leary KA, McElwee MK, Michalowski J, Eisenman RN, Powell DA, Perry ME. 2006. Tumor suppression and normal aging in mice with constitutively high p53 activity. Genes Develop 20: 16-21.

Menin C, Scaini MC, De Salvo GL, Biscuola M, Quaggio M, Esposito G, Belluco C, Montagna M, Agata S, D’Andrea E, et al. 2006. Association between MDM2-SNP309 and age at colorectal cancer diagnosis according to p53 mutation status. J Natl Cancer Inst 98: 285-288.

Momand J, Zambetti GP, Olson DC, George D, Levine AJ. 1992. The mdm-2 oncogene product forms a complex with the p53 protein and inhibits $\mathrm{p} 53$-mediated transactivation. Cell 69: 1237-1245.

Murray-Zmijewski F, Lane DP, Bourdon JC. 2006.p53/p63/ p73 isoforms: An orchestra of isoforms to harmonise cell differentiation and response to stress. Cell Death and Differentiation 13: 962-972.

Murray-Zmijewski F, Slee EA, Lu X. 2008. A complex barcode underlies the heterogeneous response of p53 to stress. Nat Rev Mol Cell Biol 9: 702-712.

Nakashima M, Kondo S, Shimizu Y, Wakisaka N, Murono S Furukawa M, Yoshizaki T. 2008. Impact of MDM2 single nucleotide polymorphism on tumor onset in head and neck squamous cell carcinoma. Acta Otolaryngol 128: 808-813.

Narod SA, Brunet JS, Ghadirian P, Robson M, Heimdal K, Neuhausen SL, Stoppa-Lyonnet D, Lerman C, Pasini B, de los Rios P, et al. 2000. Tamoxifen and risk of contralateral breast cancer in BRCA1 and BRCA2 mutation carriers: A case-control study. Hereditary Breast Cancer Clinical Study Group. Lancet 356: 1876-1881.

Niwa Y, Hirose K, Matsuo K, Tajima K, Ikoma Y, Nakanishi T, Nawa A, Kuzuya K, Tamakoshi A, Hamajima N. 2005. Association of p73 G4C14-to-A4T14 polymorphism at exon 2 and p53 Arg72Pro polymorphism with the risk of endometrial cancer in Japanese subjects. Cancer Lett 219: $183-190$

Noureddine MA, Menendez D, Campbell MR, Bandele OJ, Horvath MM, Wang X, Pittman GS, Chorley BN, Resnick MA, Bell DA. 2009. Probing the functional impact of sequence variation on p53-DNA interactions using a novel microsphere assay for protein-DNA binding with human cell extracts. PLoS Gen 5: e1000462.

Palanca Suela S, Esteban Cardeñosa E, Barragán González E, de Juan Jiménez I, Chirivella González I, Segura Huerta A, Guillén Ponce C, Martínez de Dueñas E, Montalar Salcedo J, Castel Sánchez V, et al. 2009. CASP8 D302H polymorphism delays the age of onset of breast cancer in BRCA1 and BRCA2 carriers. Breast Cancer Res Treat doi: 10.1007/s10549-009-0316-2.

Park SH, Choi JE, Kim EJ, Jang JS, Han HS, Lee WK, Kang YM, Park JY. 2006. MDM2 309T $>$ G polymorphism and risk of lung cancer in a Korean population. Lung Cancer 54: $19-24$
Peter ME. 2000. The TRAIL DISCussion: It is FADD and caspase-8! Cell Death Differentiation 7: 759-760.

Pfeifer D, Arbman G, Sun XF. 2005. Polymorphism of the p73 gene in relation to colorectal cancer risk and survival. Carcinogenesis 26: 103-107.

Philipp-Staheli J, Kim KH, Liggitt D, Gurley KE, Longton G, Kemp CJ. 2004. Distinct roles for p53, p27Kip1, and p21Cip1 during tumor development. Oncogene 23: 905-913.

Pim D, Banks L. 2004. p53 polymorphic variants at codon 72 exert different effects on cell cycle progression. Int $J$ Cancer 108: 196-199.

Pittman AM, Broderick P, Sullivan K, Fielding S, Webb E, Penegar S, Tomlinson I, Houlston RS. 2008. CASP8 variants $\mathrm{D} 302 \mathrm{H}$ and $-6526 \mathrm{~N}$ ins/del do not influence the risk of colorectal cancer in the United Kingdom population. Br J Cancer 98: 1434-1436.

Poyurovsky MV, Prives C. 2006. Unleashing the power of p53: Lessons from mice and men. Genes Develop 20: $125-131$.

Rebbeck TR, Levin AM, Eisen A, Snyder C, Watson P, Cannon-Albright L, Isaacs C, Olopade O, Garber JE, Godwin AK, et al. 1999. Breast cancer risk after bilateral prophylactic oophorectomy in BRCA1 mutation carriers. J Natl Cancer Inst 91: 1475-1479.

Riley T, Sontag E, Chen P, Levine A. 2008. Transcriptional control of human p53-regulated genes. Nat Rev Mol Cell Biol 9: 402-412.

Rodrigues FC, Kawasaki-Oyama RS, Fo JF, Ukuyama EE, Antonio JR, Bozola AR, Romeiro JG, Rahal P, Tajara EH. 2003. Analysis of CDKN1A polymorphisms: Markers of cancer susceptibility? Cancer Gen Cytogen 142: 92-98.

Roh J, Kim M, Kim J, Park N, Song Y, Kang S, Lee H. 2001. Polymorphisms in codon 31 of p21 and cervical cancer susceptibility in Korean women. Cancer Lett 165: 59-62.

Roh JW, Kim JW, Park NH, Song YS, Park IA, Park SY, Kang SB, Lee HP. 2004. p53 and p21 genetic polymorphisms and susceptibility to endometrial cancer. Gynecologic Oncol 93: 499-505.

Rowland BD, Peeper DS. 2006. KLF4, p21 and contextdependent opposing forces in cancer. Natl Rev Cancer 6: 11-23.

Ruijs MW, Schmidt MK, Nevanlinna H, Tommiska J, Aittomaki K, Pruntel R, Verhoef S, Van't Veer LJ. 2007. The single-nucleotide polymorphism 309 in the MDM2 gene contributes to the Li-Fraumeni syndrome and related phenotypes. Eur J Hum Genet 15: 110-114.

Ryan BM, McManus R, Daly JS, Carton E, Keeling PW, Reynolds JV, Kelleher D. 2001. A common p73 polymorphism is associated with a reduced incidence of oesophageal carcinoma. Br J Cancer 85: 1499-1503.

Saito S, Goodarzi AA, Higashimoto Y, Noda Y, Lees-Miller SP, Appella E, Anderson CW. 2002. ATM mediates phosphorylation at multiple p53 sites, including $\operatorname{Ser}(46)$, in response to ionizing radiation. $J$ Biol Chem 277: 12491-12494.

Sakamuro D, Sabbatini P, White E, Prendergast GC. 1997. The polyproline region of $\mathrm{p} 53$ is required to activate apoptosis but not growth arrest. Oncogene 15: 887-898. 


\section{L.F. Grochola et al.}

Sanchez-Carbayo M, Socci ND, Kirchoff T, Erill N, Offit K, Bochner BH, Cordon-Cardo C. 2007. A polymorphism in HDM2 (SNP309) associates with early onset in superficial tumors, TP53 mutations, and poor outcome in invasive bladder cancer. Clin Cancer Res 13: 3215-3220.

Shiloh Y. 2003. ATM and related protein kinases: Safeguarding genome integrity. Nat Rev Cancer 3: 155-168.

Sigurdson AJ, Bhatti P, Doody MM, Hauptmann M, Bowen L, Simon SL, Weinstock RM, Linet MS, Rosenstein M, Stovall M, et al. 2007. Polymorphisms in apoptosisand proliferation-related genes, ionizing radiation exposure, and risk of breast cancer among U.S. Radiologic Technologists. Cancer Epidemiol Biomarkers Prev 16: 2000-2007.

Sjalander A, Birgander R, Rannug A, Alexandrie AK, Tornling G, Beckman G. 1996. Association between the p21 codon $31 \mathrm{Al}(\mathrm{arg})$ allele and lung cancer. Human Heredity 46: 221-225.

Smirnov DA, Morley M, Shin E, Spielman RS, Cheung VG. 2009. Genetic analysis of radiation-induced changes in human gene expression. Nature 459: 587-591.

Soussi T, Wiman KG. 2007. Shaping genetic alterations in human cancer: The p53 mutation paradigm. Cancer Cell 12: 303-312.

Stredrick DL, Garcia-Closas M, Pineda MA, Bhatti P, Alexander BH, Doody MM, Lissowska J, Peplonska B, Brinton LA, Chanock SJ, et al. 2006. The ATM missense mutation p.Ser49Cys (c.146C $>\mathrm{G}$ ) and the risk of breast cancer. Human Mutation 27: 538-544.

Su L, Liu G, Zhou W, Xu LL, Miller DP, Park S, Lynch TJ, Wain JC, Christiani DC. 2003a. No association between the p21 codon 31 serine-arginine polymorphism and lung cancer risk. Cancer Epidemiol Biomarkers Prev 12: $174-175$.

Su L, Sai Y, Fan R, Thurston SW, Miller DP, Zhou W, Wain JC, Lynch TJ, Liu G, Christiani DC. 2003b. P53 (codon 72) and P21 (codon 31) polymorphisms alter in vivo mRNA expression of p21. Lung Cancer 40: 259-266.

Sullivan A, Syed N, Gasco M, Bergamaschi D, Trigiante G, Attard M, Hiller L, Farrell PJ, Smith P, Lu X, Crook T. 2004. Polymorphism in wild-type p53 modulates response to chemotherapy in vitro and in vivo. Oncogene 23: 3328-3337.

Sun Y, Hildesheim A, Li H, Li Y, Chen JY, Cheng YJ, Hayes RB, Rothman N, Bi WF, Cao Y, et al. 1995. No point mutation but a codon 31ser->arg polymorphism of the WAF- $1 / \mathrm{CIP}-1 / \mathrm{p} 21$ tumor suppressor gene in nasopharyngeal carcinoma (NPC): The polymorphism distinguishes Caucasians from Chinese. Cancer Epidemiol Biomarkers Prev 4: 261-267.

Swinney RM, Hsu SC, Hirschman BA, Chen TT, Tomlinson GE. 2005. MDM2 promoter variation and age of diagnosis of acute lymphoblastic leukemia. Leukemia 19: $1996-1998$.

Thomas M, Kalita A, Labrecque S, Pim D, Banks L, Matlashewski G. 1999. Two polymorphic variants of wild-type p53 differ biochemically and biologically. Mol Cell Biol 19: $1092-1100$.

Toffoli G, Biason P, Russo A, De Mattia E, Cecchin E, Hattinger CM, Pasello M, Alberghini M, Ferrari C, Scotlandi $\mathrm{K}$, et al. 2009. Effect of TP53 Arg72Pro and MDM2 SNP309 polymorphisms on the risk of high-grade osteosarcoma development and survival. Clin Cancer Res 15: 3550-3556.

Tomso DJ, Inga A, Menendez D, Pittman GS, Campbell MR, Storici F, Bell DA, Resnick MA. 2005. Functionally distinct polymorphic sequences in the human genome that are targets for p53 transactivation. Proc Nat Acad Sci 102: 6431-6436.

Vazquez A, Bond EE, Levine AJ, Bond GL. 2008. The genetics of the p53 pathway, apoptosis and cancer therapy. Nat Rev 7: 979-987.

Vikhanskaya F, Siddique MM, Kei Lee M, Broggini M, Sabapathy K. 2005. Evaluation of the combined effect of 53 codon 72 polymorphism and hotspot mutations in response to anticancer drugs. Clin Cancer Res 11: 4348-4356.

Walker KK, Levine AJ. 1996. Identification of a novel p53 functional domain that is necessary for efficient growth suppression. Proc Natl Acad Sci 93: 15335-15340.

Wasielewski M, Nagel JH, Brekelmans C, Klijn JG, van den Ouweland A, Meijers-Heijboer H, Schutte M. 2006. MDM2 SNP309 accelerates familial breast carcinogenesis independently of estrogen signaling. Breast Cancer Res Treatment 104: 153-157.

Waterman MJ, Stavridi ES, Waterman JL, Halazonetis TD. 1998. ATM-dependent activation of p53 involves dephosphorylation and association with 14-3-3 proteins. Nat Gen 19: 175-178.

Wu MT, Wu DC, Hsu HK, Kao EL, Yang CH, Lee JM. 2003. Association between p21 codon 31 polymorphism and esophageal cancer risk in a Taiwanese population. Cancer Lett 201: 175-180.

Yao Z, Duan S, Hou D, Heese K, Wu M. 2007. Death effector domain DEDa, a self-cleaved product of caspase-8/ Mch5, translocates to the nucleus by binding to ERK1/ 2 and upregulates procaspase-8 expression via a p53-dependent mechanism. EMBO J 26: 1068-1080.

Yoon YJ, Chang HY, Ahn SH, Kim JK, Park YK, Kang DR, Park JY, Myoung SM, Kim DY, Chon CY, et al. 2008. MDM2 and p53 Polymorphisms are associated with the development of hepatocellular carcinoma in patients with chronic Hepatitis B virus infection. Carcinogenesis 29: 1192-1196. 


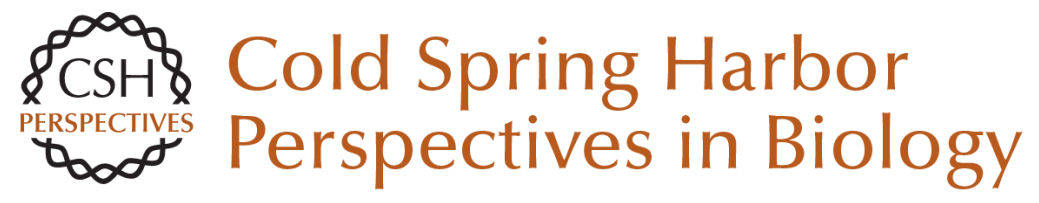

\section{Single-nucleotide Polymorphisms in the p53 Signaling Pathway}

Lukasz F. Grochola, Jorge Zeron-Medina, Sophie Mériaux and Gareth L. Bond

Cold Spring Harb Perspect Biol 2010; doi: 10.1101/cshperspect.a001032 originally published online December 9, 2009

\section{Subject Collection The p53 Family}

The Origins and Evolution of the p53 Family of Genes

Vladimir A. Belyi, Prashanth Ak, Elke Markert, et al.

Mouse Models of p53 Functions

Guillermina Lozano

TP53 Mutations in Human Cancers: Origins,

Consequences, and Clinical Use

Magali Olivier, Monica Hollstein and Pierre Hainaut

p53 Research: The Past Thirty Years and the Next

Thirty Years

David Lane and Arnold Levine

Transcriptional Regulation by P53

Rachel Beckerman and Carol Prives

p53-based Cancer Therapy

David P. Lane, Chit Fang Cheok and Sonia Lain

Phylogeny and Function of the Invertebrate p53

Superfamily

Rachael Rutkowski, Kay Hofmann and Anton Gartner

Tied Up in Loops: Positive and Negative

Autoregulation of p53

Xin Lu
The Tumor Suppressor p53: From Structures to

Drug Discovery

Andreas C. Joerger and Alan R. Fersht

p53 Regulation of Metabolic Pathways

Eyal Gottlieb and Karen H. Vousden

The Regulation of the p53-mediated Stress

Response by MDM2 and MDM4 Mary Ellen Perry

Zebrafish Models of p53 Functions Narie Y. Storer and Leonard I. Zon

p63 and p73, the Ancestors of p53

V. Dötsch, F. Bernassola, D. Coutandin, et al.

Pathologies Associated with the p53 Response Andrei V. Gudkov and Elena A. Komarova

Single-nucleotide Polymorphisms in the p53

Signaling Pathway

Lukasz F. Grochola, Jorge Zeron-Medina, Sophie Mériaux, et al.

Clinical Outcomes and Correlates of TP53

Mutations and Cancer

Ana I. Robles and Curtis C. Harris

For additional articles in this collection, see http://cshperspectives.cshlp.org/cgi/collection/

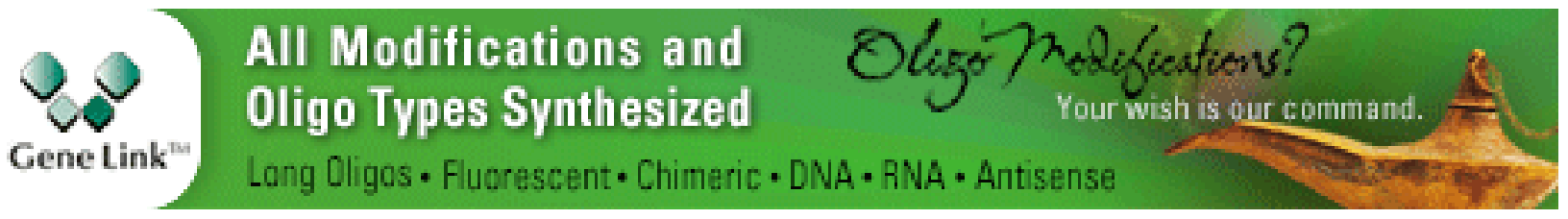

Copyright @ 2010 Cold Spring Harbor Laboratory Press; all rights reserved 